\title{
Opportunity Makes the Cheater: High School Students and Academic Dishonesty
}

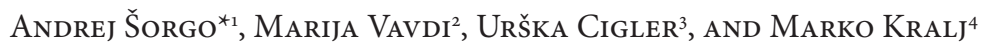

$\approx$ The purpose of this study was to reveal data about cheating behaviours in Slovenian upper secondary schools, to raise awareness and to lower tolerance for such behaviour. To acquire information about demographics, cheating behaviour, and opinions on such behaviour, we compiled a questionnaire that targeted a university population of first-year students $(\mathrm{N}=323)$. From the results, it was revealed that cheating is a way of life in Slovenian schools, and almost all students at least occasionally indulge in some academic misbehaviour. It seems that a culture tolerant or even supportive of such behaviour has been established among students, parents and teachers, all working together to "help" students climb the ladder of success. The open question is whether all kinds of cheating are even recognized as such. Cheating is most common in homework, but at the other end, even systems such as external exams are not immune to fraud. At the moment, classic methods of cheating dominate. Differences between characters (e.g. gender) and educational institutions in most cases are non-existent or small, a finding that could aid in establishing measures to prevent cheating inside schools as institutions.

Keywords: cheating, academic dishonesty, secondary school

$1 \quad$ Corresponding Author. University of Maribor, Faculty of Natural Sciences and Mathematics; University of Maribor, Faculty of Electrical Engineering and Computer Science, Slovenia; andrej.sorgo@um.si

2 University of Maribor, Faculty of Natural Sciences and Mathematics, Slovenia

3 University of Maribor, Faculty of Natural Sciences and Mathematics, Slovenia

4 University of Maribor, Faculty of Natural Sciences and Mathematics, Slovenia 


\section{Priložnost dela goljufa: srednješolci in akademske nečednosti}

ANdrej Šorgo*, MariJa VAVdi, UrŠKa Cigler in Marko Kralj

$\propto$ Cilj študije je bil pridobiti podatke o goljufanju v šoli med slovenskimi srednješolci z namenom dvigniti zavedanje o tem pojavu in znižati toleranco do njega. Da bi pridobili ustrezne podatke o goljufanju in stališča o njem med srednješolci, smo sestavili vprašalnik, ki smo ga posredovali študentom prvih letnikov univerze $(\mathrm{N}=322)$. Iz zbranih rezultatov lahko sklenemo, da je goljufanje "način življenja« v slovenskih srednjih šolah in da so dejansko vsi dijaki vsaj občasno udeleženi v kateri izmed oblik goljufanja. Ugotavljamo, da se je v šolah med dijaki, starši in učitelji razvila kultura, ki celo podpira goljufanje. Ravnanje opravičujejo s ciljem pomagati dijakom, da bi se laže vzpenjali po lestvici uspeha. Odprto ostaja vprašanje, ali so nekatere oblike goljufanja sploh prepoznane kot goljufanje. Goljufanje je najpogosteje prisotno pri domačih nalogah, vendar celo matura ni imuna na zlorabe. Razlik med spoloma in različnimi šolami nismo zaznali ali pa so te majhne. To spoznanje lajša vpeljavo ukrepov, s katerimi bi lahko zmanjšali število goljufij, povezanih z izobraževanjem v šolah.

Ključne besede: goljufanje, akademske nečednosti, srednja šola 


\section{Introduction}

Academic cheating, academic dishonesty, and academic misconduct can be recognized as umbrella terms for a range of behaviour from copying an answer over a shoulder, to falsifying the results or presenting other's work as one's own. In a broad context, they are close to the corruption, recognized as a threat to academic integrity (Heyneman, 2004, 2014; Transparency International, 2013). All such behaviour has in common that the academically dishonest person gains real or perceived benefit from breaking established rules (Green, 2004). Definitions of academic dishonesty are not exact, nor is the list of behaviours (Burrus, McGoldrick, \& Schuhmann, 2007), and definitions differ greatly across cultures (Magnus, Polterovich, Danilov, \& Savvateev, 2002; Grimes, 2004; Šimić Šašić \& Klarin, 2009). It is particularly easy to cross the line between family support and cheating in homework and home assignments (Bouville, 2010; Walker \& Townley, 2012). Because of rapid developments in information and communication technologies (ICT), new forms of cheating are emerging (e.g., Selwyn, 2008; Hamlen, 2012; Trushell, Byrne, \& Hassan, 2013).

The impetus behind the study was to gain insight into the phenomenon of high school cheating in Slovenia. That high school students cheat is common knowledge; however, academic studies are rare and exist mostly in the form of unpublished undergraduate theses. Where more rigorous studies do exist, the intention of such studies is not to quantify cheating behaviours, but to study teacher-student relationships (e.g. Peklaj, Kalin, Pecjak, Zuljan Valencic, \& Levpuscek Puklek, 2012) or to focus on higher education levels (Pšunder, 2001; Gadpaille, 2004). In addition to academic curiosity, we would like to raise awareness about dishonest behaviour among high school students in attempts to lower the frequency and tolerance of such behaviour. Common knowledge is that problems in secondary education help cause the problems in higher education and subsequently into the labour market. In addition, tolerance even to the benign forms of school cheating can lead to erosion of academic integrity consisted of "honesty, trust, respect, fairness and responsibility" (Heyneman, 2014, p. 4), and "fundamental to the reputation of academic institutions" (p. 4).

Academic dishonesty cannot be regarded as a benign folk practice spanning the globe but as one of the threats to the reliability of grades and competences learned at school (Bouville, 2010). The real problem arises when final grades constitute entrance prerequisites for another educational level. As stated by Bouville (2010, p. 70), "If grades are used to decide who should be admitted to a top university, a smart and talented student, a student with a tutor, and a cheater will look the same even though the first is superior to the other two." 
The Matura and the Vocational Matura, for example, are the high stakes schoolleaving exams for secondary education that influence teaching in Slovenia (Pšunder \& Harl, 2008). Matura enables candidates to enrol in all programmes of tertiary education, while the Vocational Matura enables candidates to enrol in vocational colleges and colleges but not in university courses (The National Examinations Centre, online). In cases in which there are more students than places offered, grades from the Matura or Vocational Matura are used at some faculties and colleges as exclusive selection criteria. The reported number of rule violations of exam guidelines at the external Matura is low. According to the reports of the Matura committee in 2012 and 2013, in each year, nine cases of cheating were reported among 8601 students enrolled for Matura in 2013, and 8617 in 2012 (The National Examinations Centre, online).

In the first part, our research was not hypothesis driven but exploratory in design. No prior hypotheses were set up. Our intention was to find answers to several research questions and to clarify differences between various groups (gender and type of school). In the second part, we were interested in finding connections between the frequency of academic misbehaviour as an outcome variable and the reasons for and opinions about cheating as predictor variables in addition to external demographic factors. As a theoretical background, the theory of planned behaviour was used (Ajzen, 1991, 2002).

The prior research questions were as follows:

- How frequently do secondary school students cheat?

- Which forms of cheating are more common than others?

- What are the most important reasons for cheating in schools?

- What are students' opinions of/attitudes toward cheating?

- How often do students cheat on external Matura exams?

- $\quad$ Are there differences in cheating between genders, subjects and types of school?

We were more interested in whole population results, and the search for differences was not a primary aim of our research. The practical reason was that knowledge about these can have academic value but is of little practical value in establishing measures to be taken against cheating inside schools as institutions. We can be aware of differences and can respect them but, for example, we cannot prepare separate rules for boys and girls to prevent misbehaviour.

\section{Methods}

The study was performed at the Faculty of Natural Sciences and Mathematics, University of Maribor, Slovenia. We gained the initial inspiration for 
our work from a study conducted by Šimić Šašić and Klarin (2009) in Bosnia and Herzegovina and Croatia. Later, the initial study was adapted and changed for our purposes.

\section{Data collection}

Data were collected between December 2013 and January 2014 by the authors of the study. The questionnaire was administered to the students before or after lectures in a paper and pencil format. Students participated on the freewill basis, and anonymity was guaranteed because the collectors did not know the names of the participants and questionnaires were collected in a random order. The collected questionnaires were randomized and the data were transferred into spreadsheets. The target population comprised first-year students of different faculties at the University of Maribor, Slovenia. Using this design, we were able to collect responses from a variety of Slovenian secondary schools from the class of 2009-2013. Owing to our guarantee of anonymity and because their responses cannot harm their reputation or influence their careers, a high level of honesty was expected (Yardley, Rodriguez, Bates, \& Nelson, 2009). Altogether, we received responses from 323 students: 117 males, 203 females, and three who did not answer; 244 (75.5\%) had finished general secondary school with the general Matura exam, and 79 (24.5\%) had finished technical schools with the Vocational Matura. The sample represents about $7.5 \%$ of all first-year students at the University of Maribor $(\mathrm{N}=4281)$ and about $3.1 \%$ of all students participating at the Matura exams in $2013(\mathrm{~N}=7814)$ in Slovenia.

\section{Instruments}

A questionnaire was compiled with tables assessing their demographics, cheating behaviour, and opinions on such behaviour.

\section{Forms of cheating}

The instrument consists of 21 confirmative statements (items) describing various aspects of cheating (Table 1). We compiled statements from a pool of 17 statements from a study about cheating among Croatian and Bosnian and Herzegovinian students (Šimić Šašić \& Klarin, 2009), to which some original statements were added. We asked students about the frequency of dishonest behaviour on a scale between very frequently (5) and never (1). The scale was not structured, and only five numbers were provided between extremes. This was 
a difference from the study by Šimić Šašić and Klarin. They used a three-point scale (never, 1-2 times, more times). The instrument has good or even very good internal consistency (Cronbach's alpha $=0.88$ ) (Field, 2009). As a summative measure of involvement in actual misbehaviour, we summed responses to 20 items. In such a case, someone who performs all types of misbehaviour very frequently will end up with the sum of 100, and someone who never exhibits such behaviour with the sum of 20 . The statement "I have observed cheating in school" was excluded from the pool of actual cheating because it is passive in nature. Following Kolmogorov-Smirnov statistics $(\mathrm{N}=323 ; \mathrm{Z}=1.84 ; \mathrm{p}=0.02)$, the distribution of the sums is normal with $\mathrm{M}=43.30$ and $\mathrm{SD}=10.92$ with a minimum $=21$ and a maximum $=94$.

Exploratory factorial analysis following initial checking for suitability of the data for such analysis was executed $(\mathrm{KMO}=0.86$; Barlett's test of sphericity $=2386.63,210 \mathrm{df} ; \mathrm{p}<0.001$ ). Principal component analysis with Varimax rotation was performed, and five factors explaining $58.2 \%$ of variance were extracted.

\section{Reasons for cheating}

To identify reasons for cheating 18 statements (Table 3 ) were provided, and students were asked to indicate the frequency with which they indulged in such behaviour on a scale between very frequently (5) and never (1). We used 18 statements from a 24-item scale used by Šimić Šašić and Klarin (2009). As in the case of types of cheating, the scale was not structured, and only numbers were provided. The difference from the study of Šimić Šašić and Klarin lay not only in the number of items but in the response format. They used a Likert-type format from totally disagree (1) to totally agree (5). In this way, we did not obtain information about intentions and attitudes but about actual behaviour according to the theory of planned behaviour (Ajzen, 1991, 2002). The instrument has good or even very good internal consistency (Cronbach's alpha = o.89) (Field, 2009).

\section{Cheating on the external Matura exams}

To identify whether students were involved in cheating during Matura examinations, we used a two-tier question. The first question was: "Have you cheated during Matura exams?" and the second "Did you observe or get knowledge about cheating on the Matura exams?". In the first part of the question students answered with "yes" or "no", and if they answered positively, they were 
asked to provide information about the subjects of cheating and forms of cheating used in an open response.

\section{Opinions on cheating}

Five statements concerning cheating were provided (Table 4). The response format was the Likert type on the following scale: totally disagree (1), disagree (2), neutral, do not care (3) agree (4), and totally agree (5). Our intention was not to prepare a one-dimensional instrument but that each statement should be explained separately. Because of the nature of the statements, reliability was not calculated, and only descriptive statistics was performed on the data. Differences were calculated as effect size (Field, 2009).

\section{Statistical analyses}

The data were checked for missing data and outliers prior to further analyses. Cases with a large number of empty fields were deleted. Normality was checked by use of the Kolmogorov-Smirnoff test at the 0.05 significance level. Where our data did not meet the assumption of normality, nonparametric statistics was performed to compare between groups (Erceg-Hurn \& Mirosevich, 2008). Effect size was calculated with the equation $r=Z / \sqrt{ } N$; where $Z=$ Kolmogorov-Smirnov $\mathrm{Z}$ and $\sqrt{ } \mathrm{N}$ = square root of the sample size (Field, 2009, p. 550). Because of the structure of the instruments, no negative coding was necessary.

Where exploratory factorial analysis was performed, Principal Component Analysis with Varimax Rotation and Kaiser Normalization was chosen. Prior to the analysis, Kaiser-Meyer-Olkin (KMO) measure of sampling adequacy and Bartlett's test of sphericity were used to check data suitability for further analysis. Due to the lack of a normal distribution, results from the Principal Component Analysis should be considered with caution (Basto \& Pereira, 2012).

To find predictors of dishonest behaviour, linear regression analysis was executed. As a measure of dishonest behaviour, a sum of the 20 items from the Forms of Cheating instrument was used.

All statistical analyses were performed using SPSS 21.0 software.

\section{Results}

Results are presented in the form of tables and accompanied by comments. 
Table 1. Forms and frequency of cheating among secondary school students. Results are ordered by decreasing values of Mean

\begin{tabular}{|c|c|c|c|c|c|c|c|c|}
\hline & Statement & $\mathrm{N}$ & Mean & SD & Med & Mod & GES & SES \\
\hline 1 & I have observed cheating in school. & 322 & 4.03 & 0.94 & 4 & 5 & 0.17 & 0.04 \\
\hline 15 & $\begin{array}{l}\text { I have allowed schoolmates to copy my } \\
\text { homework. }\end{array}$ & 322 & 3.66 & 1.114 & 4 & 4 & 0.14 & 0.14 \\
\hline 17 & $\begin{array}{l}\text { I have allowed schoolmates to copy an- } \\
\text { swers during written assessments (tests). }\end{array}$ & 322 & 3.41 & 1.038 & 3 & 3 & 0.01 & 0.14 \\
\hline 16 & $\begin{array}{l}\text { I have whispered to classmates during } \\
\text { oral or written assessments. }\end{array}$ & 322 & 2.98 & 1.038 & 3 & 3 & 0.03 & 0.01 \\
\hline 8 & $\begin{array}{l}\text { I have communicated with classmates } \\
\text { during written assessment of knowledge. }\end{array}$ & 319 & 2.77 & 1.055 & 3 & 2 & 0.03 & 0.00 \\
\hline 3 & I have helped other students to cheat. & 322 & 2.75 & 1.105 & 3 & 2 & 0.11 & 0.01 \\
\hline 12 & $\begin{array}{l}\text { I have copied homework, a presentation, } \\
\text { an essay or something similar. }\end{array}$ & 321 & 2.72 & 1.121 & 3 & 2 & 0.05 & 0.19 \\
\hline 2 & I have cheated in school. & 322 & 2.55 & 0.934 & 2 & 2 & 0.04 & 0.02 \\
\hline 14 & $\begin{array}{l}\text { I have used a cheat sheet during assess- } \\
\text { ments. }\end{array}$ & 320 & 2.51 & 1.136 & 2 & 2 & 0.07 & 0.05 \\
\hline 4 & $\begin{array}{l}\text { During written knowledge assessment I } \\
\text { have copied from others. }\end{array}$ & 322 & 2.37 & 0.981 & 2 & 2 & 0.08 & 0.08 \\
\hline 13 & I have lent my cheat sheet to classmates. & 320 & 2.35 & 1.238 & 2 & 1 & 0.03 & 0.02 \\
\hline 10 & I have lied to the teacher. & 321 & 1.83 & 0.951 & 2 & 1 & 0.15 & 0.08 \\
\hline 6 & $\begin{array}{l}\text { I have obtained test questions illegally } \\
\text { before the test. }\end{array}$ & 322 & 1.59 & 0.843 & 1 & 1 & 0.06 & 0.05 \\
\hline 9 & $\begin{array}{l}\text { When knowledge assessment was an- } \\
\text { nounced, I have skipped school. }\end{array}$ & 320 & 1.59 & 0.758 & 1 & 1 & 0.04 & 0.14 \\
\hline 18 & $\begin{array}{l}\text { I have searched for a completed lab } \\
\text { report on the internet and submitted it to } \\
\text { the teacher. }\end{array}$ & 322 & 1.56 & 0.892 & 1 & 1 & 0.17 & 0.04 \\
\hline 19 & $\begin{array}{l}\text { I have copied a part or a whole essay } \\
\text { from the internet and submitted it as my } \\
\text { own work. }\end{array}$ & 322 & 1.54 & 0.893 & 1 & 1 & 0.27 & 0.02 \\
\hline 21 & $\begin{array}{l}\text { I have copied outlines to a mobile phone } \\
\text { and used them during assessment. }\end{array}$ & 322 & 1.54 & 1.008 & 1 & 1 & 0.14 & 0.02 \\
\hline 11 & $\begin{array}{l}\text { I have counterfeited a grade or an apol- } \\
\text { ogy for absence. }\end{array}$ & 321 & 1.51 & 0.969 & 1 & 1 & 0.04 & 0.10 \\
\hline 20 & $\begin{array}{l}\text { I have searched for correct answers using } \\
\text { a mobile phone during assessments. }\end{array}$ & 322 & 1.47 & 0.897 & 1 & 1 & 0.09 & 0.02 \\
\hline 7 & $\begin{array}{l}\text { During evaluation, I have received or sent } \\
\text { solutions to tasks with a mobile phone. }\end{array}$ & 322 & 1.43 & 0.873 & 1 & 1 & 0.08 & 0.01 \\
\hline 5 & $\begin{array}{l}\text { I have obtained a higher score with the } \\
\text { help of acquaintances. }\end{array}$ & 322 & 1.20 & 0.596 & 1 & 1 & 0.03 & 0.11 \\
\hline
\end{tabular}

GES = values of effect size between genders; SES = values of effect size between general and professional secondary schools 
Table 2. Frequency of self-reported cheating (I have cheated in school) on a scale between never (1) and very frequently (5)

\begin{tabular}{llcccc}
\hline & & Frequency & Percent & Valid Percent & Cumulative Percent \\
\hline \multirow{4}{*}{ Valid } & 1 & 27 & 8.4 & 8.4 & 8.4 \\
& 2 & 151 & 46.7 & 46.9 & 55.3 \\
& 3 & 100 & 31.0 & 31.1 & 86.3 \\
& 4 & 28 & 8.7 & 8.7 & 95.0 \\
& 5 & 16 & 5.0 & 5.0 & 100.0 \\
& Total & 322 & 99.7 & 100.0 & \\
\hline Missing & System & 1 & 0.3 & & \\
\hline Total & \multicolumn{5}{c}{100.0} \\
\hline
\end{tabular}

When searching for the type and frequency of cheating, it was revealed that the highest values (mode $=5$ ) (Table 2 ) were given to the statement that they had observed cheating in school $(\mathrm{N}=120,37.3 \%)$. Only three (3) students (0.9\%) reported that they had never observed it. In combination with the answer about direct involvement in cheating ("I have cheated in school"), for which only 27 students $(8.4 \%)$ reported that they had never cheated and that others did it at least occasionally $(\operatorname{Mod}=2)$ (Table 1$)$, it was possible to draw the conclusion that academic dishonesty (cheating) is a "normal way" of functioning at higher secondary schools in Slovenia. Differences can be recognized in the frequency of types of cheating (Table 1). When the results were ranked, the question arose of whether if some forms of academic dishonesty are in reality even recognized as cheating by students. For example, the mode (2), median (2) and mean (2.55) of answers about personal involvement in cheating ("I have cheated in school") are lower than the values of six answers regarding different types of personal involvement: e.g. "I have allowed schoolmates to copy my homework." (Mod = 4; Med = 4; M = 3.66) (Table 1).

Reported use of mobile devices for cheating is rare and, at the moment, still unimportant, and classic methods are more common than e-cheating. The lowest scores go to the statement "I have obtained a higher score with the help of acquaintances."

Differences between genders (GES) and type of school (SES = general, technical/professional) (Table 1) calculated as effect sizes are in most cases insignificant or small, with values below 0.2 (Field, 2009). Only in one item ("I have copied part of or a whole essay from the internet and submitted it as my own work") does the value (o.27) fall to the rank of medium, and in favour of males. 
Direct or indirect tolerance of misbehaviour by teachers cannot be directly identified from our study. Nevertheless, it seems that teachers are at least occasionally intentionally or unintentionally involved in dishonesty. From the finding that 13 students (4.1\%) reported numbers 4 and 5 (very common) for obtaining tests illegally, it could be inferred that the involvement of teachers in cheating is probable. The involvement of some teachers in misbehaviour is additionally supported by the responses of $13.7 \%$ of students that they had obtained a higher score with the help of acquaintances.

Five factors were revealed explaining almost $60 \%$ of the variance, allowing the grouping of cheating behaviour in clusters. The first three factors have a Cronbach's alpha above 0.7 , so their reliability can be recognized as satisfactory. In the first factor (17.3\%), are grouped "classic" school cheating behaviour (e.g., using cheat sheets or copying). In the second factor (11.7\%) are grouped the use of mobile devices and other persons not present in the classroom (e.g. obtaining test questions illegally); these can be recognized as obtaining help from others. In the third factor (10\%), helping others can be recognized as the leading idea. The fourth factor $(10 \%)$ can be called plagiarism, and in the fifth factor (9.5\%) are severe violations of rules.

Table 3. Reasons for cheating among secondary school students. Results are ordered by decreasing values of the Mean

\begin{tabular}{|c|c|c|c|c|c|c|c|c|}
\hline & Statement & $\mathrm{N}$ & Mean & SD & Med & Mod & GES & SES \\
\hline 17 & $\begin{array}{l}\text { I have cheated when there was lax } \\
\text { supervision during knowledge assess- } \\
\text { ment. }\end{array}$ & 322 & 3.25 & 1.295 & 3.00 & 3 & 0.006 & 0.15 \\
\hline 3 & $\begin{array}{l}\text { I have cheated because I wanted to } \\
\text { achieve good grades. }\end{array}$ & 323 & 3.17 & 1.226 & 3.00 & $3^{\mathrm{a}}$ & 0.15 & 0.09 \\
\hline 13 & $\begin{array}{l}\text { I have cheated when the seating order } \\
\text { allowed it. }\end{array}$ & 323 & 2.80 & 1.269 & 3.00 & 3 & 0.04 & 0.04 \\
\hline 11 & $\begin{array}{l}\text { I fear punishment if I were to be } \\
\text { caught while cheating. }\end{array}$ & 320 & 2.79 & 1.375 & 3.00 & 1 & 0.22 & 0.05 \\
\hline 7 & $\begin{array}{l}\text { I have cheated because I did not suc- } \\
\text { ceed in absorbing all the content. }\end{array}$ & 323 & 2.78 & 1.185 & 3.00 & 3 & 0.08 & 0.15 \\
\hline 18 & $\begin{array}{l}\text { I have cheated when there was poor } \\
\text { organization of grading. }\end{array}$ & 323 & 2.78 & 1.334 & 3.00 & 3 & 0.06 & 0.05 \\
\hline 15 & $\begin{array}{l}\text { I have cheated when assessment was } \\
\text { too heavy for me. }\end{array}$ & 321 & 70 & 1.237 & 3.00 & 3 & 0.07 & 0.02 \\
\hline 2 & $\begin{array}{l}\text { I have cheated because I ran out of } \\
\text { time. }\end{array}$ & 323 & 2.67 & 1.181 & 3.00 & 3 & 0.15 & 0.15 \\
\hline
\end{tabular}




\begin{tabular}{|c|c|c|c|c|c|c|c|c|}
\hline 10 & $\begin{array}{l}\text { I have cheated because I wanted to } \\
\text { help a classmate. }\end{array}$ & 321 & 2.62 & 1.211 & 3.00 & 3 & 0.03 & 0.14 \\
\hline 4 & $\begin{array}{l}\text { I have cheated because I did not want } \\
\text { to bother studying. }\end{array}$ & 323 & 2.58 & 1.298 & 2.00 & 2 & 0.22 & 0.06 \\
\hline 14 & $\begin{array}{l}\text { I have cheated when grading was } \\
\text { important. }\end{array}$ & 321 & 2.48 & 1.263 & 2.00 & 1 & 0.06 & 0.003 \\
\hline 1 & $\begin{array}{l}\text { I have cheated because of too many } \\
\text { out-of-school activities. }\end{array}$ & 323 & 2.10 & 1.093 & 2.00 & 1 & 0.01 & 0.03 \\
\hline 16 & $\begin{array}{l}\text { I have cheated when the task was not } \\
\text { announced in advance. }\end{array}$ & 323 & 2.05 & 1.216 & 2.00 & 1 & 0.10 & 0.01 \\
\hline 5 & $\begin{array}{l}\text { I have cheated for a teacher I did not } \\
\text { like. }\end{array}$ & 323 & 1.86 & 1.150 & 1.00 & 1 & 0.13 & 0.005 \\
\hline 8 & $\begin{array}{l}\text { I have cheated because I had low } \\
\text { grades. }\end{array}$ & 323 & 1.65 & .941 & 1.00 & 1 & 0.09 & 0.19 \\
\hline 12 & $\begin{array}{l}\text { I have cheated because parents and } \\
\text { relatives expected good grades from } \\
\text { me. }\end{array}$ & 321 & 1.60 & .924 & 1.00 & 1 & 0.06 & 0.01 \\
\hline 9 & $\begin{array}{l}\text { I have cheated because I couldn't get } \\
\text { good grades otherwise. }\end{array}$ & 323 & 1.59 & .951 & 1.00 & 1 & 0.1006 & 0.01 \\
\hline 6 & $\begin{array}{l}\text { I have cheated because other students } \\
\text { were better than me. }\end{array}$ & 323 & 1.29 & 0.618 & 1.00 & 1 & 0.03 & 0.04 \\
\hline
\end{tabular}

GES = values of effect size between genders; SES = values of effect size between general and professional secondary schools

At the top of the perceived reasons for cheating are two statements (Table 3), which taken together give insight into why and when students cheat. The combined statement is as follows: "I cheated because I wanted to achieve good grades and there was lax supervision during knowledge assessment." At the bottom are three statements showing the relative unimportance of external pressure to fulfil the expectations of parents, low self-esteem, and the wish to compete with other students as incentives toward cheating. Fear of being caught and punished is high in some students, but most of them $(\bmod =1)$ do not have such feelings. Differences between genders (GES), type of school (SES = general, technical/professional) calculated as effect sizes are in most cases insignificant or small with values below 0.2 (Field, 2009).

We obtain better insight into the reasons when answers are grouped. Four factors explaining $61.1 \%$ of variance concerning the reasons for cheating were extracted (Table 3). Only the first three factors, with a Cronbach's alpha above 0.7 , were considered to be reliable, while the fourth factor is most probably a construct of two unrelated answers. The first factor $(20.5 \%)$ comprises three answers connected with flawed organization (modus = 3) (e.g. "I have cheated when there was poor organization of grading"), the impulse to help a 
schoolmate and to a lesser extent with personal distress (e.g. "I have cheated when grading was important"). While the first three items are clearly connected and highlight opportunity and low-level risk as the background for flawed behaviour, the relations between the other items in the factor are not as clear. The second factor (18\%) comprises personal distress related to reasons such as a shortage of study time, the prevalence of other interests over school duties, and poor organization of time. All items in the third factor (16\%) are items with low frequency and are connected with external pressures and the drive to obtain better grades.

Regression analysis revealed that when the sum of cheating behaviours was used as the outcome and 18 items from the reasons for the cheating instrument (Table 3 ) used as predictors, about $60 \%$ of the variance $\left(\mathrm{R}^{2}=0.595\right)$ is explained. Five items (data not shown) are positive predictors of cheating behaviour at the $\mathrm{p}<0.05$ levels. These items are as follows: "I have cheated because I did not want to bother studying."; "I have cheated with a teacher I did not like", "I have cheated because I wanted to achieve good grades", "I have cheated when the seating order allowed", and "I have cheated because I wanted to help a classmate". The statement "I fear punishment if I were to be caught while cheating" is, in contrast, a negative predictor of cheating behaviour.

\section{Cheating on the external Matura exams}

From 322 students, 306 (95\%) reported that they had not cheated during these exams and 16 (5\%) that they had. Numbers (320, 3 missing) in favour of dishonest behaviour are higher when students were asked if they had observed or had been informed about cheating during exams: 266 (82.4\%) reported that they had not witnessed such behaviour and 54 (16.7\%) that they had. Copying was reported in seven cases, use of cheat sheets in four cases and use of a mobile phone in two cases. Three cases are unclear. The most common forms of observed cheating were copying (21), cheat sheets (13), whispering or sign communication (11) and the use of technical devices (10) such as mobile phones, smart watches or a graphic calculator. Reported variants in the use of cheat sheets include sheets hidden in a lavatory, pencil cases, pens, clothes, calculators or even written on one's skin. Technically advanced communication with the use of the Internet is reported in one case. From the answers, it was possible to conclude that multiple choice tests are most vulnerable to cheating, because someone need only signal the number of the test item and one letter. It seems that in some cases the whole class was involved in such signalling. 


\section{Opinions on cheating}

Table 4. Opinions on academic cheating

\begin{tabular}{|c|c|c|c|c|c|c|c|c|}
\hline & Statement & $\mathrm{N}$ & $M$ & SD & Med & Mod & GES & SES \\
\hline 3 & $\begin{array}{l}\text { Cheating is frequent because of the lack } \\
\text { of serious consequences. }\end{array}$ & 323 & 3.51 & 1.070 & 4 & 4 & 0.11 & 0.07 \\
\hline 1 & $\begin{array}{l}\text { Cheating in school is ethically question- } \\
\text { able. }\end{array}$ & 322 & 3.16 & 0.964 & 3 & 3 & 0.05 & 0.11 \\
\hline 5 & $\begin{array}{l}\text { Cheating is the natural state of human } \\
\text { nature, so it must be expected. }\end{array}$ & 323 & 3.06 & 1.151 & 3 & 4 & 0.13 & 0.001 \\
\hline 2 & $\begin{array}{l}\text { Cheating in school is acceptable by } \\
\text { society. }\end{array}$ & 322 & 2.81 & 0.960 & 3 & 3 & 0.02 & 0.03 \\
\hline 4 & $\begin{array}{l}\text { Cheating in school is acceptable because } \\
\text { everyone does it. }\end{array}$ & 323 & 2.80 & 1.038 & 3 & 2 & 0.02 & 0.04 \\
\hline
\end{tabular}

GES = values of effect size between genders; SES = values of effect size between general and professional secondary schools

Table 5. Regression coefficients of opinions as predictors and the sum of cheating behaviours as outcome

\begin{tabular}{|c|c|c|c|c|c|c|}
\hline \multicolumn{7}{|c|}{ Coefficients $^{\mathrm{a}}$} \\
\hline \multicolumn{2}{|c|}{ Model } & \multicolumn{2}{|c|}{$\begin{array}{l}\text { Unstandardized } \\
\text { Coefficients }\end{array}$} & \multirow{2}{*}{$\begin{array}{c}\begin{array}{c}\text { Standardized } \\
\text { Coefficients }\end{array} \\
\text { Beta }\end{array}$} & \multirow[t]{2}{*}{$t$} & \multirow[t]{2}{*}{ Sig. } \\
\hline & & B & Std. Error & & & \\
\hline \multirow{6}{*}{1} & (Constant) & 42.254 & 3.904 & & 10.824 & 0.000 \\
\hline & $\begin{array}{l}\text { Cheating in school is ethically ques- } \\
\text { tionable. }\end{array}$ & -2.460 & 0.636 & -0.221 & -3.868 & 0.000 \\
\hline & $\begin{array}{l}\text { Cheating is the natural state of human } \\
\text { nature, so it must be expected. }\end{array}$ & 1.266 & 0.525 & 0.136 & 2.412 & 0.016 \\
\hline & $\begin{array}{l}\text { Cheating in school is acceptable by } \\
\text { society. }\end{array}$ & 1.355 & 0.630 & 0.120 & 2.151 & 0.032 \\
\hline & $\begin{array}{l}\text { Cheating in school is acceptable } \\
\text { because everyone does it. }\end{array}$ & 0.871 & 0.572 & 0.084 & 1.523 & 0.129 \\
\hline & $\begin{array}{l}\text { Cheating is frequent because of the } \\
\text { lack of serious consequences. }\end{array}$ & -0.407 & 0.531 & -0.040 & -0.765 & 0.445 \\
\hline
\end{tabular}

a. Dependent Variable: sum of cheating behaviours

The highest agreement (Table 4 ) occurred with the statement that cheating is frequent $(\bmod =4 ; \operatorname{med}=4)$ because of a lack of serious consequences. This response can be connected with the reasons for cheating (Table 3) and can be taken as an explanation for the first factor (Opportunity). However, the statement is a poor predictor of actual behaviour (Table 5) and can be, as 
such, regarded as common knowledge. Also falling into the category of common knowledge not affecting behaviour is the statement "Cheating in school is acceptable because everyone does it", which can be regarded as a group norm (Rettinger \& Kramer, 2009). In support of cheating behaviour, but to a lesser extent, can be added the opinion that cheating is the natural state of human nature, so it must be expected, and that cheating in school is acceptable by society. Overall, the list of provided opinions was not a good predictor of actual cheating behaviour $\left(\mathrm{R}^{2}=0.153\right)$. Among them, the best predictor of someone not cheating is the opinion that cheating in school is ethically questionable. The statement is negatively correlated $(\mathrm{r}=-0.320, \mathrm{p}<0.01)$ with the sum of cheating behaviours, so we can assume that attitudes and values do prevent cheating in students. In all items, differences between genders (GES) and type of school (SES = general, technical/professional) (Table 5) calculated as effect sizes are in most cases insignificant or small, with values below 0.2 (Field, 2009).

\section{Discussion}

The finding that almost all high school students from our sample had at least occasionally cheated (91.4\%) or had observed cheating (99.1\%) during their high school years was higher than expected but is not a surprise and places Slovenian students in line with findings worldwide (e.g. McCabe, Trevino, \& Butterfield, 2001; Šimić Šašić \& Klarin, 2009; Galloway, 2012). From the differences in the reported frequency of different kinds of misbehaviour, cheating cannot simply be indicated as a unitary concept but instead as a family of related behaviours (Newstead, Franklyn-Stokes, \& Armstead, 1996) and should be handled in follow-up studies at least by groups of related behaviours. The first group includes prevailing methods of cheating recognized as "classic", such as copying or the use of cheat-sheets. There is no fool-proof method against this kind of cheating, a finding that was revealed from the data about cheating on Matura exams for which strict measures against cheating are taken, and the consequences, if a student is caught, are severe.

According to Ajzen's theory of planned behaviour (1991), there should be three strands of actions to lower "classic" cheating. The first strand is to lower the level of tolerance for such behaviour (subjective norm) (O'Rourke et al., 2010). The second can be recognized as technical and involves the control and prevention of such behaviour and prevention by generating, for example, different variants of a test or seating order (perceived behavioural control). The third is in changing attitudes toward such behaviour (Rettinger \& Kramer, 2009; Mayhew, Hubbard, Finelli, Harding, \& Carpenter, 2009). Following 
the recommendations of Heyneman (2004) to prevent corruption in education these include reforms to (i) educational structures, (ii) the processes of management and adjudication, (iii) the mechanisms of prevention and when wrongdoing occurs, (iv) the system of sanctions.

New methods with the use of mobile and electronic devices in the classroom are rare. Helping others can be recognized as the leading idea and important background reason for cheating. The real question that needs further elaboration and conclusion but which cannot be extracted from our study is what, in reality, is recognized as cheating by our students. For example, allowing someone to copy homework is most probably not regarded as cheating but as helping one's peers and simply follows from receiving help from parents, which is recognized by society as something positive and to be encouraged (Bong, 2008; Fan, Williams, \& Wolters, 2012). Because classrooms in Slovenian schools are stable structures based on predominantly obligatory subjects and a student is assigned to a class at the beginning of schooling (which in reality means that a class can have the same members for nine years in elementary and three or four- years in upper secondary schools), strong peer-to-peer relations are established, which favour cooperative behaviour instead of competition among peers. Five of six cases with higher frequency in reports of cheating (Table 1) can be grouped as "altruistic cheating" (Green, 2004) because direct benefit for the cheater in terms of school success cannot be attributed to such behaviour (e.g. "I have allowed schoolmates to copy my homework."). Our study does not allow us to reach definite conclusions on this issue but clearly suggests the existence of a non-competitive culture and peer support among students. The difference between allowing copying and copying from others cannot be easily explained, but is probably a result of the grouping of higher-achieving students at university who were able to do their homework on their own and to offer assistance to their lower-achieving peers, who were not included in the observed population. Prevention of cheating in this group is probably the most difficult issue to be dealt with. It is known that cheating is lower in competitive cultures, but the question is whether it lies in our interest to transform a cooperative classroom culture into a competitive one. In our opinion, this will be a digression on the route towards cooperative society or enterprises. While copying during tests can be suppressed by stricter supervision, the issue is somewhat more difficult with homework assignments. Because most forms of such cheating are performed outside regular school classes or in breaks, regular control mechanisms are not applicable. One possible solution is to assign unique homework to each student, a measure that seems unlikely because of the additional workload for teachers, and the omission of exercises in gap-fill short answer formats. 
Plagiarism comprises related behaviours, yet a clear definition of plagiarism is elusive (e.g. Wager, 2014). Plagiarism is not a new phenomenon but one that has become much easier with the use of the Internet (Selwyn, 2008; Lau \& Yuen, 2014) and the cut-and-paste functions embedded in word processing software. In contrast, identification of plagiarism has become much easier with existing and emerging software. Studies at the undergraduate, graduate, and professional levels are numerous but are much rarer at secondary school levels (Ercegovac \& Richardson, 2004; Sisti, 2007). The unanswered question that arises from our study is, if whether the copying of others' works is even recognized as cheating. The second order question is whether teachers recognize it either. It would be unrealistic to expect that individual teachers have sources for identifying every cause of plagiarism because they must in everyday practice handle hundreds of reports, homework, essays, and other material. The solution lies in clear definitions of unethical behaviour and in raising the ethical level of student behaviour.

Severe violations of rules, such as grade counterfeiting or corruption are in actual school practice rare. It is unrealistic to expect that they can be completely eradicated from schools, as is the case with other formats of unethical behaviour in society, such as doping in sport or drug abuse. The knowledge that something cannot be eradicated does not mean that it should be tolerated; instead, it calls for the establishment of well-defined honour codes of instructional culture bearing in mind that such a culture should not produce new inequities (Kennedy-Lewis, 2014).

Based on the revealed three-factor structure (Table 3 ), the most probable excuse of the statistical "ghost student" for cheating would be the statement: "I have cheated because I wanted to achieve good grades, but I did not have enough time to study, and the chance of being caught was low." Transferring this statement into something like, "I achieved good grades because of good time management and no need to cheat, even if I do not fear being caught" is beyond the reach of efforts by a single teacher (e.g. Reinhard, Dickhaeuser, Marksteiner, \& Sporer, 2011). At the practical level, the simplest plan would be for teachers and institutions to reduce their tolerance of cheating and take action to prevent it. However, in reality, it would be even more important to change attitudes and norms so as to modify student behaviour in the direction of honest classroom practices. Changing adolescents' behaviour cannot be the responsibility of the school alone, but whole families (Brown-Wright et al., 2013), academic institutions (McCabe et al., 2001) or communities must be involved.

The figures for cheating on the external Matura exams are lower (5\%) but far higher than the numbers in official reports from the Matura committee. 
Because the consequences for a cheater are severe (exclusion from the Matura exam), it seems that the discrepancy between our numbers and the reported numbers is not merely a consequence of students' smart methods of cheating, but that (at least in some cases because of) cheating that has been detected is being ignored by teachers for emotional reasons or because of the effort required to deal with cheating students (Keith-Spiegel, Tabachnick, Whitley, \& Washburn, 1998). At the narrative level, there are rumours supported by our research in one reported case that on several occasions a teacher did help students on tests. We cannot give a definitive answer on the issue of possible involvement by teachers, but we can speculate that helping students is a form of defence against losing their reputation or the reputation of their schools because of a higher number of students failing exams.

It was revealed that five opinions provided in our study (Table 4) were poor predictors $\left(\mathrm{R}^{2}=0.153\right)$ of actual cheating behaviour; therefore, no major conclusions can be extracted. Nevertheless, our findings do support the idea that students who agree with the idea that "Cheating in school is ethically questionable" will cheat less frequently. Potential cheaters are more commonly supporters of these opinions "Cheating is the natural state of human nature, so it must be expected", and "Cheating in school is acceptable by society". These findings call for additional effort by instructors and communities to change attitudes toward cheating.

\section{Conclusions}

The bad news revealed from our study is that cheating is a "way of life" in Slovenian schools: almost all students at least occasionally indulge in some academic misbehaviour. Even more, it seems a culture tolerant or even supportive of such behaviour that has been established among groups of students, parents and teachers - all working together to "help" students climb the ladder of success. The open question is whether all kinds of cheating are even recognized as such. Cheating is most common in homework but at the other end, even systems such as external examinations are not immune to fraud. At the moment, classic methods of cheating dominate, but penetration by e-cheating can be foreseen.

From the practical, cynical viewpoint, the good news from our study is that differences between characters (e.g. gender) and educational institutions in most cases are non-existent or small; this could help in establishing measures against cheating within schools as institutions. Teachers or institutions can be aware of differences and can respect them but, for example, they cannot prepare 
separate rules based on characters or traits to prevent misbehaviour. Because of such minimal differences, actions addressing all involved can be prepared regardless of differences.

The present study has only scratched the surface to uncover some deep rooted problems, so additional studies are necessary for basis of establishing programmes to reduce the level of acceptability and its concomitant practices.

\section{References}

Ajzen, I. (1991). The Theory of Planned Behavior. Organizational Behavior and Human Decision Processes, 50, 179-211.

Ajzen, I. (2002). Perceived Behavioral Control, Self-Efficacy, Locus of Control, and the Theory of Planned Behavior. Journal of Applied Social Psychology, 32, 665-683.

Basto, M., \& Pereira, J. M. (2012). An SPSS R-Menu for Ordinal Factor Analysis. Journal of Statistical Software, 46(4), 1-29.

Bong, M. (2008). Effects of parent-child relationships and classroom goal structures on motivation, help-seeking avoidance, and cheating. Journal of Experimental Education, 76(2), 191-217.

Bouville, M. (2010). Why is Cheating Wrong? Studies in Philosophy and Education, 29(1), 67-76. Brown-Wright, L., Tyler, K. M., Stevens-Watkins, D., Thomas, D., Mulder, S., Hughes, T., StevensMorgan, R., Roan-Belle, C., Gadson, N., \& Smith, L. (2013) Investigating the Link Between HomeSchool Dissonance and Academic Cheating Among High School Students. Urban Education, 48(2), 314-334.

Burrus, R. T., McGoldrick, K. M., \& Schuhmann, P. W. (2007). Self-reports of student cheating: Does a definition of cheating matter? Journal of Economic Education, 38(1), 3-16.

Erceg-Hurn, D. M., \& Mirosevich, V. M. (2008). Modern robust statistical methods: an easy way to maximize the accuracy and power of your research. American Psychologist, 63(7), 591-601.

Ercegovac, Z., \& Richardson, J. V. (2004). Academic dishonesty, plagiarism included, in the digital age: A literature review. College \& Research Libraries, 65(4), 301-318.

Fan, W., Williams, C. M., \& Wolters, C. A. (2012). Parental Involvement in Predicting School Motivation: Similar and Differential Effects Across Ethnic Groups. Journal of Educational Research, 105(1), 21-35.

Field, A. (2009). Discovering statistics using SPSS, $3^{\text {rd }}$ edition. London: Sage Publications.

Gadpaille, M. (2004). Academic integrity in a European context. European English Messenger, 13(1), 57-59.

Galloway, M. K. (2012). Cheating in Advantaged High Schools: Prevalence, Justifications, and Possibilities for Change. Ethics \& Behavior, 22(5), 378-399.

Green, S. P. (2004). Cheating. Law and Philosophy, 23(2), 137-185.

Grimes, P. W. (2004). Dishonesty in academics and business: a cross-cultural evaluation of student attitudes. Journal of Business Ethics, 49, 273-290. 
Heyneman, S. P. (2004). Education and Corruption, International Journal of Educational

Development, 24(6), 637-648.

Heyneman, S. P. (2014). How Corruption puts Higher Education at Risk. International Higher

Education, 75(Spring), 3-5.

Keith-Spiegel, P., Tabachnick, B. G., Whitley, B. E., \& Washburn, J. (1998). Why professors ignore cheating: Opinions of a national sample of psychology instructors. Ethics \& Behavior, 8(3), 215-227.

Kennedy-Lewis, B. L. (2014) Using critical policy analysis to examine competing discourses in zero tolerance legislation: do we really want to leave no child behind? Journal of Education Policy, 29(2), 165-194.

Lau, W. W. F., \& Yuen, A. H. K. (2014). Internet ethics of adolescents: Understanding demographic differences. Computers \& Education, 72, 378-385.

Magnus, J. R., Polterovich, V. M., Danilov, D. L., \& Savvateev, A. V. (2002). Tolerance of cheating: An analysis across countries. Journal of Economic Education, 33(2), 125-135.

Mayhew, M. J., Hubbard, S. M., Finelli, C. J., Harding, T. S., \& Carpenter, D. D. (2009). Using Structural Equation Modeling to Validate the Theory of Planned Behavior as a Model for Predicting Student Cheating. Review of Higher Education, 32(4), 441-468.

McCabe, D. L., Trevino, L. K., \& Butterfield, K. D. (2001). Cheating in academic institutions: A decade of research. Ethics \& Behavior, 11(3), 219-232.

Newstead, S. E., Franklyn-Stokes, A., \& Armstead, P. (1996). Individual differences in student cheating. Journal of Educational Psychology, 88(2), 229-241.

O’Rourke, J., Barnes, J., Deaton, A., Fulks, K., Ryan, K., \& Rettinger, D. A. (2010). Imitation is the Sincerest Form of Cheating: The Influence of Direct Knowledge and Attitudes on Academic Dishonesty. Ethics \& Behavior, 20(1), 47-64.

Peklaj, C., Kalin, J., Pecjak, S., Zuljan Valencic, M., \& Levpuscek Puklek, M. (2012). Perceptions of Teachers' Goals in Classroom, Students' Motivation and their Maladaptive Behavior as Predictors of High School Math Achievement. Studia Psychologica, 54(4), 329-344.

Pšunder, M., \& Harl, N. (2008). Connection between matura and didactic implementation of educational process in general upper secondary schools. Didactica-Slovenica-Pedagoska-obzorja, $23(3-4), 105-124$.

Pšunder, M. (2001). Cheating in exams. Scientia paedagogica experimentalis, 38(2), 133-142. Reinhard, M-A., Dickhaeuser, O., Marksteiner, T., \& Sporer, S. L. (2011). The case of Pinocchio: teachers' ability to detect deception. Social Psychology of Education, 14(3), 299-318.

Rettinger, D. A., \& Kramer, Y. (2009). Situational and Personal Causes of Student Cheating. Research in Higher Education, 50(3), 293-313.

Selwyn, N. (2008). 'Not necessarily a bad thing ... ': a study of online plagiarism amongst undergraduate students. Assessment \& Evaluation In Higher Education, 33(5), 465-479. Šimić Šašić, S., \& Klarin, M. (2009). Varanje u srednjim školama u Hrvatskoj i u Bosni i Hercegovini. [Cheating in secondary schools in Croatia and Bosnia and Herzegovina]. Društvena istraživanja, 18(6/104), 999-1022. 
Sisti, D. A. (2007). How do high school students justify Internet plagiarism? Ethics \& Behavior, 17(3), 215-231.

The National Examinations Centre, online. Retrieved from http://www.ric.si/ric_eng/general_ information/

Transparency international (2013). Higher education institutions: Why they matter and why corruption puts them at risk. Global Corruption Report: Education. Transparency International. New York City: Routledge.

Trushell, J., Byrne, K., \& Hassan, N. (2013) ICT facilitated access to information and undergraduates' cheating behaviours. Computers \& Education, 63, 151-159.

Wager, E. (2014). Defining and responding to plagiarism. Learned Publishing, 27(1), 33-42.

Walker, M., \& Towley, C. (2012). Contract cheating: a new challenge for academic honesty? Journal of Academic Ethics, 10(1), 27-44.

Yardley, J., Rodriguez, M. D., Bates, S. C., \& Nelson, J. (2009). True Confessions?: Alumni’s Retrospective Reports on Undergraduate Cheating Behaviors. Ethics \& Behavior, 19(1), 1-14.

\section{Biographical note}

Dr. ANDreJ Šorgo is an associate professor of Biology Didactics at the Faculty of Natural Sciences and Mathematics, and a part time researcher at the Faculty of Electrical Engineering and Computer Science, University of Maribor. He got his Master and PhD degree in Biology from University of Ljubljana. He has published textbooks, research articles and presented his work at a number of conferences. He has additionally over 20 years' of experience as secondary and higher vocational school teacher. He was awarded with »The most innovative secondary school teacher award «.

MARIJA VAVDI, graduated in Educational Biology and Educational Mathematics and received Master degree in Educational Biology and Educational Mathematics from the Faculty of Natural Sciences and Mathematics, University of Maribor, Slovenia. She has interest in research on environmental issues, and published article based on her thesis in the professional journal. She is co-author of laboratory manuals in Biology for general upper secondary schools.

UrŠKA CigLER, graduated in Educational Biology and Educational Mathematics and received Master degree in Educational Biology and Educational Mathematics from the Faculty of Natural Sciences and Mathematics, University of Maribor, Slovenia. She has interest in evaluation of laboratory methods, and is co-author of laboratory manuals in Biology for general upper secondary schools. 
Marko KralJ, graduated in Educational Biology and Educational Chemistry and is recently Master student of Educational Biology and Educational Chemistry at the Faculty of Natural Sciences and Mathematics, University of Maribor, Slovenia. His focus is on integration of educational technology into education. He participated in educational projects and as a student presented his work at the international conference Eduvision. 